\title{
Article \\ Impacts of Technology Training Provided by Agricultural Cooperatives on Farmers' Adoption of Biopesticides in China
}

\author{
Yuying Liu ${ }^{1}$, Ruiling Shi ${ }^{2}$, Yiting Peng ${ }^{2}$, Wei Wang ${ }^{2}$ and Xinhong Fu ${ }^{2, *}$ \\ 1 Sichuan Center for Rural Development Research, College of Management, Sichuan Agricultural University, \\ Chengdu 611130, China; yuying.liu@sicau.edu.cn \\ 2 Faculty of Agricultural Economics and Management, College of Management, Sichuan Agricultural \\ University, Chengdu 611130, China; 201706202@stu.sicau.edu.cn (R.S.); yitingpeng@stu.sicau.edu.cn (Y.P.); \\ wangwei@sicau.edu.cn (W.W.) \\ * Correspondence: 10248@sicau.edu.cn; Tel.: +86-153-8823-0048
}

Citation: Liu, Y.; Shi, R.; Peng, Y.; Wang, W.; Fu, X. Impacts of Technology Training Provided by Agricultural Cooperatives on Farmers' Adoption of Biopesticides in China. Agriculture 2022, 12, 316. https://doi.org/10.3390/ agriculture12030316

Academic Editor: Oscar E. Liburd

Received: 18 January 2022

Accepted: 16 February 2022

Published: 22 February 2022

Publisher's Note: MDPI stays neutral with regard to jurisdictional claims in published maps and institutional affiliations.

Copyright: (c) 2022 by the authors. Licensee MDPI, Basel, Switzerland. This article is an open access article distributed under the terms and conditions of the Creative Commons Attribution (CC BY) license (https:// creativecommons.org/licenses/by/ $4.0 /)$.

\begin{abstract}
As pesticide abuse becomes increasingly serious worldwide, it is necessary to pay attention to the biopesticide adoption behavior of agricultural producers. It is worth verifying whether agricultural cooperatives, as training organizations sharing the same social network with farmers, can promote the adoption of biopesticides through their technology diffusion function. Therefore, based on survey data of 837 citrus producers in Sichuan Province, China, the IV-probit regression model and a mediation effects model were used to empirically test the impact of technical training on farmers' adoption of biopesticides in addition to its mechanism, considering the farmers' perception of technology as the mediation variable. The results show that (a) participation in technical training can significantly enhance the probability of the adoption of biopesticides; (b) farmers' perceptions of biopesticides' economic and health benefits play a partial mediating role in the relationship; and (c) technical training has more significant effects on biopesticides adoption behavior for a household with higher-educated household heads, lower household total income, and smaller household size, relative to their counterparts. This study provides evidence for establishing relevant policy to encourage the full adoption of the technical training function of agricultural cooperatives and popularize the use of biopesticides.
\end{abstract}

Keywords: agricultural cooperatives; technology training; biopesticide adoption; technology perception

\section{Introduction}

In China, $7 \%$ of the world's arable land is used to feed $22 \%$ of the world's population, due to the usage of pesticides [1]. However, along with the chronic overuse of pesticides, serious agricultural diffuse pollution is developing, which could not only damage the ecological environment but also threaten food safety [1]. More seriously, it is reported that pesticide usage by Chinese farmers reached three times the global average [2]. To effectively alleviate the harm caused by the use of traditional pesticides, the Chinese Ministry of Agriculture has introduced a series of measures, such as the "Action to Achieve Zero Growth of Pesticide Use by 2020" [3]. Biopesticides are considered to be safe for humans and the environment, as well as a sustainable alternative to conventional pesticides due to their lower toxicity than conventional pesticides [4-6]. Nevertheless, the use of biopesticides remains low in developing countries [7].

A lack of knowledge about the use of biopesticides is considered to be the main reason why smallholder farmers are less likely to use biopesticides [8]. Thus, increasing farmers comprehensive understanding of biopesticides should be a valuable measure with which to facilitate the broader use of biopesticides. For adults, training is an effective way to increase the cognition of new concepts [9]. More specifically, the technical perception of smallholder farmers could be enhanced via training on the economic, scientific, legal, 
and technical aspects of pesticides [10,11]. For example, Yu et al. found that technical training is the most effective way to help farmers adopt new technologies after comparing measurements of the acquisition of new technology by farmers [12]. Mannan et al. argued that the involvement of farmer in-field training could significantly improve their technical understanding and practical abilities, thereby promoting their adoption of green fertilizer technology [13]. Furthermore, among the organizations that provide training to farmers, agricultural cooperatives embedded in the rural social network can offer specific advantages in training farmers and promoting agricultural technology by providing face-to-face, repeated, and in-field training. Thus, agricultural cooperatives, as a training organization, are well-developed in developing countries [14-17].

Research exploring the role of agricultural cooperatives in the technological diffusion of agricultural production has confirmed that membership of agricultural cooperatives promotes green control technologies, safe production behavior, and environmental production practices among farmers [14,16-18]. For example, Ma and Abdulai adopted the endogenous transformation model and used the variable of membership in cooperatives as the key explanatory variable, indicating that agricultural cooperatives could become an effective way to spread integrated pest management (IPM) technology [14]. However, not all farmers who join cooperatives will automatically benefit from cooperatives. In other words, only those who receive the training services of agricultural cooperatives can be affected by the training function of agricultural cooperatives [19]. To our knowledge, no research has either given an answer as to whether the training provided by agricultural cooperatives can drive the adoption of biopesticides by farmers or explained the mechanism by which the training provided by agricultural cooperatives affects the adoption of biopesticides by farmers.

Therefore, the primary objective of this study was to provide a more rigorous assessment of the impact of the technical training provided by agricultural cooperatives on farmers' adoption of biopesticides, encouraging the full adoption of the function of agricultural cooperatives in technology diffusion. This study contributes to the research on technical training, agricultural cooperative service function, and agricultural technology diffusion in three ways. First, we empirically analyzed the effects of the technical training provided by agricultural cooperatives on farmers' adoption of biopesticides in the context of severe environmental pollution. Previous studies have identified the impact of technical training on farmers' adoption of agricultural technologies [20-22]; however, they have not focused on the effects of training subjects' differences in farming technology adoption. Furthermore, we focused on the training function of agricultural cooperatives. Although agricultural cooperatives may play a much more significant role in training farmers, relevant studies are absent from the body of research. Second, we analyzed the mediation effect of farmers' perceptions of technology (i.e., biopesticides) on the relationship between the technical training provided by agricultural cooperatives and farmers' adoption of biopesticides. Some studies have shown that improving farmers' perceptions of the long-term consequences of pesticide use could enhance their likelihood of practicing pesticide safety behavior and indicated that education and training could improve farmers' levels of understanding [23]. However, the other studies also found that farmers' awareness of safety production was necessary but not sufficient to inspire farmers to use safety measures [24]. Since previous studies have emphasized the role of cognition in technology adoption but failed to obtain a unified opinion, this study further discusses the influence of the technical training provided by agricultural cooperatives on farmers' technology adoption from the perspective of farmers' understanding of technology. Third, we used the IV-probit model to control the endogeneity caused by the bidirectional causality between technical training participation behavior and biopesticide adoption behavior.

The rest of the study is structured as follows. In Section 2, we present the theoretical framework and hypotheses. Section 3 presents the data, model, and variable selection, while Section 4 presents the empirical results. Section 5 describes the heterogeneous impacts. Section 6 presents the conclusions and discusses the policy implications of this study. 


\section{Theoretical Framework and Hypotheses}

The primary objective of this study is to provide a more rigorous assessment of the impact of technical training on farmers' adoption of biopesticides, in addition to its mechanism. The theoretical analysis and empirical estimation of the direct effects (reflected in hypothesis 1 (H1).) can prove whether the technical training provided by agricultural cooperatives can promote the adoption of biopesticides by farmers. The theoretical analysis and empirical estimation of mediating effects (reflected in hypothesis $2 \mathrm{a}(\mathrm{H} 2 \mathrm{a})$., hypothesis $2 \mathrm{~b}(\mathrm{H} 2 \mathrm{~b})$. , and hypothesis $2 \mathrm{c}(\mathrm{H} 2 \mathrm{c})$.) can provide more detailed information for policymakers and training providers with which to make correct decisions to popularize the use of biopesticides.

\subsection{The Effect of the Biopesticide Technical Training Provided by Agricultural Cooperatives on Farmers' Adoption Behavior}

Following Schultz in Transforming Traditional Agriculture [25], human capital investment is crucial in transforming conventional agriculture. By accumulating human capital, farmers can understand the benefits of advanced technology, master the use of advanced technology, and then promote the popularization of such technology among farmers. Additionally, human capital is mainly acquired through three methods: schoolbased education, learning by doing, and training [9]. For farmers, technical training is one of the manifestations of human capital investment and the main channel of human capital accumulation $[22,26]$. Thus, technical training is a means that should not be ignored in popularizing biopesticides [1]. Additionally, studies have found that technical training introduces advanced production techniques to farmers and teaches farmers how to use technologies, which could change farmers' awareness of green control technologies and cause them to switch from traditional production behavior to green production behavior [27]. Therefore, we believe that technical training can be used to learn about biopesticides, increase knowledge of safe pesticide application, and promote the use of biopesticides by farmers.

Previous studies have confirmed that on-site, face-to-face training with practical demonstrations contributes to the adoption of new technologies [28,29]. For example, Nakano et al. indicated that farmer-to-farmer training could encourage farmers to adopt new technology [28]. Pan et al. found that hands-on and in-field training formats appeared to be more effective than one-time, lecture-based training [29]. Additionally, some studies pointed out that informal social networks could help disseminate agricultural knowledge and the adoption of agricultural techniques [30,31]. Therefore, this study believes that agricultural cooperatives embedded in the rural social network can have specific advantages in training farmers and promoting agricultural technology by providing face-to-face, repeated, and in-field training.

These advantages are reflected in the following aspects. First of all, as cooperative economic organizations voluntarily established by farmers' households, agricultural cooperatives and farmers' households are in similar ecological environments. On the one hand, agricultural cooperatives can accurately determine which types of biopesticides are suitable for the production needs of local farmers to provide them with more accurate biopesticides. On the other hand, the language used in training by agricultural cooperatives may be more in line with the cognitive dimensions of local farmers. Thus, agricultural cooperatives usually provide farmers with pre-production, in-production, and post-production services [32], which help farmers adopt relevant production technologies after training. Specifically, first, as a marketing channel, agricultural cooperatives can, to some extent, alleviate the concern of farmers that the high quality of agricultural products cannot receive a favorable price after the adoption of green production technology. Previous studies have indicated that agricultural cooperatives could provide farmers with safer and better markets as well as help them enter the security market with strict requirements [33]. These cooperatives can improve farmers' selling prices to a certain extent $[18,22,33]$. Second, following the collective action theory, agricultural cooperatives can achieve the unified procurement of 
production materials [34]. By providing usable biopesticides, agricultural cooperatives can overcome the central contradiction that farmers face in adopting biopesticides, i.e., they do not know where to purchase biopesticides [8,35].

Furthermore, based on the above daily services, farmers have a firm trust in agricultural cooperatives [18] and are more likely to adopt biopesticides after being trained by them. Additionally, according to the peer effect, the training provided by agricultural cooperatives contains theoretical explanation and practical operation. After being trained by agricultural cooperatives, farmers could consult neighbors who have participated in the training simultaneously or directly ask the trainers of agricultural cooperatives for help in practice to deepen their mastery of technology. Last, but not least, as the International Cooperative Alliance (ICA) has mentioned that the community is a cooperative principle [36]. In addition to improving farmers' ability to participate in the market, agricultural cooperatives also guide farmers to pay attention to health and protect the environment from non-institutional aspects, such as social networks and social reputation [11].

Above all, this study considers that the training in the use of biopesticide technology provided by agricultural cooperatives can promote the adoption of biopesticides. Additionally, the more cooperative training times, the more pronounced the training effect. As a result, farmers have greater enthusiasm for adopting biological pesticides, since cooperative agricultural training improves farmers' perceptions of biological pesticides and helps farmers to solve problems in adopting biopesticides. Accordingly, the following hypothesis is proposed in this study.

Hypothesis 1 (H1): Technical training provided by agricultural cooperatives has a statistically significant positive effect on the adoption of biopesticides by farmers.

\subsection{The Mediation Effect of Farmers' Technology Perception between Biopesticide Technical Training Provided by Agricultural Cooperatives and Farmers' Adoption Behavior}

Training is an effective means to enhance farmers' awareness of new technologies [26], and the understanding of new technology can influence its adoption by farmers [1,22]. According to the analysis in 2.1, agricultural cooperatives can provide farmers with face-toface, repeated, and in-field training. This kind of training can influence farmers' adoption behavior by influencing their understanding of the long-term economic, health, and ecological benefits brought by biopesticides.

Specifically, the market principle of high quality and competitive prices has become the driving force for farmers to use biopesticides [37]. In technical training, the economic benefits of the technology would be explained first. Agricultural cooperatives would also first explain the economic benefits of biopesticides, especially the long-term financial benefits, when conducting training. Because agricultural cooperatives have fixed office places and are closely connected with farmers, farmers trust them. As a result, after acquiring knowledge from the training provided by agricultural cooperatives, farmers are more likely to form a correct understanding of the economic benefits of biopesticides. The technical training of agricultural cooperatives mainly affects farmers' understanding of the economic benefits of biopesticides through the following two channels. First, by improving farmers' access to green agricultural products, information limitations help farmers form a perception of the economic benefits of biopesticides. In the context of small farmers and large markets, farmers usually face the hurdle of incomplete market information. It is difficult for small-household farmers to grasp market information on green agricultural products. The technical training provided by agricultural cooperatives can help farmers obtain a large amount of market information about green agricultural products, through which the disadvantages of farmers in relation to information acquisition can be alleviated. Second, given their low level of education, it is difficult for farmers to understand the longterm economic value of using biopesticides. The technical training provided by agricultural cooperatives can provide repeated theoretical knowledge to farmers and provide on-the- 
spot guidance and training. This would help them overcome the limitations mentioned above.

Furthermore, agricultural cooperatives are concerned with farmers' economic needs and livelihoods (including the physical and mental health of farmers) [38,39]. Regarding the health benefits of using biopesticides, agricultural cooperatives would pay more attention to guiding farmers to focus on their health and inform them as to the health-friendly characteristics of biopesticides when conducting technical training. After attending the technical training provided by agricultural cooperatives, farmers' health utility expectations regarding the use of biopesticides would be improved, forming farmers' perceptions of the health benefits of biopesticides. Furthermore, Schreinemachers et al. mentioned that the more aware farmers are of pesticides, the more knowledgeable they are about reducing the health effects of pesticide use [7]. To improve farmers' expectations of environmental utility from biopesticides, technical training provided by agricultural cooperatives can help farmers understand the environmentally friendly characteristics of biopesticides.

More importantly, improving farmers' awareness would significantly increase their likelihood of adopting relevant technologies [1,22,29]. Sharifzadeh et al. noticed that the perception of pesticide hazards improved farmers' safety production behavior when using field survey data from rice producers in Iran [24]. Based on rice farmers' data in China, Liu et al. indicated that raising awareness of low-carbon technologies could enhance the likelihood of farmers adopting soil testing and fertilization technologies [22]. Zhang et al. pointed out that farmers' concern for the environment and awareness of pesticide residues can significantly improve their willingness to adopt ecological pesticides [1]. Ali et al. pointed out that the perceptions of the consequences of production behavior have a statistically significant effect on farmers' production behavior [40]. In the context of this study, it is the effect of the perception of the economic benefits, health benefits, and environmental impact of the use of biopesticides. Thus, we also speculate that farmers' perceptions of biopesticides could have significant effects on their adoption of biopesticides.

Above all, the following hypotheses are proposed in this study:

Hypothesis 2a (H2a): Farmers' economic perceptions mediate the relationship between the biopesticide technical training provided by agricultural cooperatives and biopesticide adoption behavior.

Hypothesis $\mathbf{2 b} \mathbf{( H 2 b ) : ~ F a r m e r s ' ~ h e a l t h ~ p e r c e p t i o n s ~ m e d i a t e ~ t h e ~ r e l a t i o n s h i p ~ b e t w e e n ~ t h e ~ b i o p e s t i - ~}$ cide technical training provided by agricultural cooperatives and biopesticide adoption behavior.

Hypothesis 2c (H2c): Farmers' environmental perceptions mediate the relationship between the biopesticide technical training provided by agricultural cooperatives and biopesticide adoption behavior.

Figure 1 shows the theoretical model of this study.

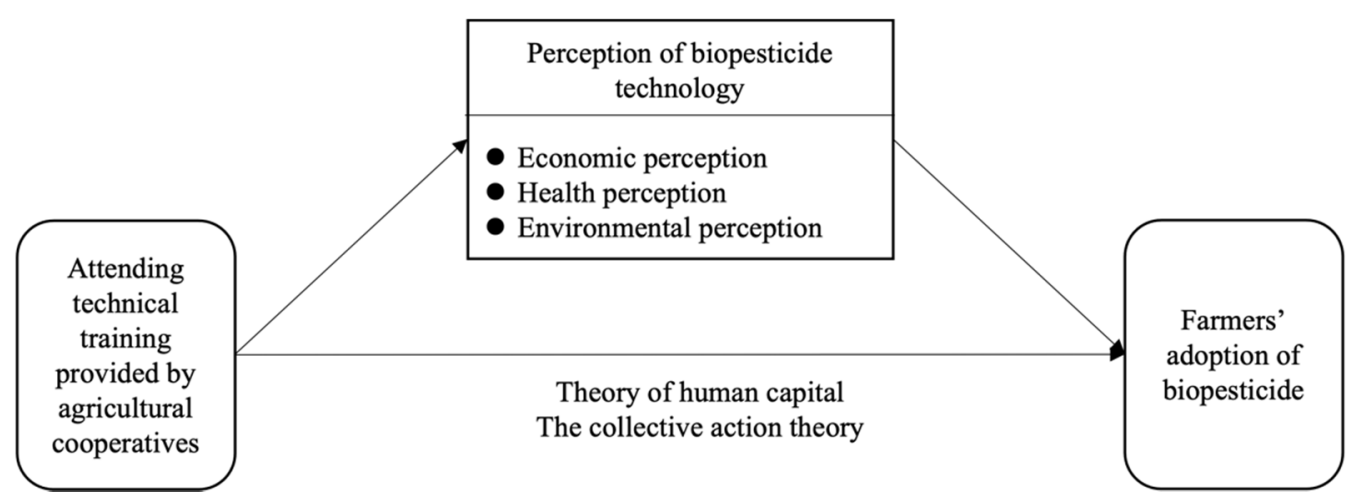

Figure 1. Theoretical model. 


\section{Model, Data, and Variables}

\subsection{Model Specification}

\subsubsection{Benchmark Model}

Given our interest in examining the impact of the biopesticide technical training provided by agricultural cooperatives on farmers' biopesticide adoption behavior, following Constantine et al. [10], farmers were directly asked whether they had used biopesticides in the planting process in the past year. We employed a dummy variable to represent a farmer who adopted biopesticides as our dependent variable. To test hypothesis 1 (H1)., proposed based on the theory of human capital and collective action theory in Section 2.1, it was assumed that farmers' adoption of biopesticides could be expressed as a technical training function. Since the dependent variable was discrete, both the Probit model and logit model could be used to estimate Equation (1). The $f(X)$ in Equation (1) is a cumulative distribution function and was assumed to be normally distributed, which was verified based on the survey data; thus, we eventually used the Probit model for the estimation. The equation was as follows:

$$
P(Y=1 \mid X)=f(\alpha+\beta X+W \gamma)
$$

where $Y$ represents the biopesticide adoption behavior of farmers. In particular, $Y$ takes the value of one if the farmer adopted biopesticides and zero otherwise. $X$ is an observed continuous variable, indicating the times that farmers participated in the technical training provided by agricultural cooperatives on biopesticides. $W$ is a vector of households and farm-level characteristics (e.g., age, gender, education, household size, household income, and so on); $\alpha$ is a constant term; and $\beta$ and $\gamma$ are parameters to be estimated.

\subsubsection{An Instrumental-Variable-Based Probit Model (IV-Probit Model)}

The estimated results of the effect of the technical training provided by agricultural cooperatives on farmers' biopesticide adoption behavior may be biased due to endogenous problems. To be specific, there may be a causal relationship between technical training participation and biopesticide technology adoption. As discussed earlier, technical training participation behavior may affect biopesticide technology adoption. Meanwhile, farmers biopesticide adoption behavior may also affect their decision as to whether to participate in technical training. Thus, the times of farmers' participation in the technical training provided by agricultural cooperatives, the core independent variable, may be endogenous. When such an endogeneity problem is prevalent, the Probit model will usually produce inconsistent and biased results. To control such endogeneity problems, following previous studies [41,42], the IV-Probit model was used for an estimation employing the instrumental variable method, and the equations were as follows:

$$
\begin{gathered}
X=\partial+W \mu+\tau V+\varepsilon \\
Y=\alpha_{1}+\beta_{1} X+W \gamma_{1}+\lambda_{1}
\end{gathered}
$$

where, $\partial$ and $\alpha_{1}$ are constant terms; $\mu, \tau, \beta_{1}$, and $\gamma_{1}$ are parameters to be estimated; and $\varepsilon$ and $\lambda_{1}$ are error terms. $V$ is an instrumental variable, which is expected to affect the decision over whether to participate in the technical training provided by agricultural cooperatives, but does not affect the adoption of biopesticides. Equation (2) is used to estimate the factors that affect the times of farmers' participation in the technical training provided by agricultural cooperatives. Equation (3) is used to estimate the impact of the technical training provided by agricultural cooperatives on the adoption of biopesticides.

Identifying a suitable instrument is the primary challenge for IV analysis. Following previous studies $[43,44]$ and the theory of peer effects, the selection of instrumental variables is based on the mean value of the times of participation in the technical training provided by agricultural cooperatives by other farmers in the same village, except for those interviewed (from now on referred to as "ratio of training"). Suppose that 
$V_{\text {training }}=\left(\right.$ training $_{1}+$ training $_{2}+\ldots+$ training $\left._{n-1}\right) /(n-1)$, where $n$ is the total number of sample farmers in this study. Specifically, farmers are more likely to participate in the technical training provided by agricultural cooperatives if their neighbors do so. Meanwhile, the times other villagers join in the technical training offered by agricultural cooperatives do not affect farmers' application of biopesticides. Furthermore, Chi-square test statistics (Wald $\chi^{2}$ ) were used to determine whether the core independent variable is endogenous. According to the test statistics results $(p<0.001)$, the times of participation in technical training provided by agricultural cooperatives are endogenous variables.

\subsubsection{The Mediation Effect Model}

According to the theory analysis in Section 2.2, farmers' perceptions of technology may mediate the relationship between the biopesticide technical training provided by agricultural cooperatives and biopesticide adoption behavior. To test the mediating effect of farmers' perception of technology, following the mediation effect model developed by Baron and Kenny [45], we used the following three models:

$$
\begin{gathered}
Y=\alpha_{2}+c X+W \mu_{1}+e_{1} \\
M=\alpha_{3}+a X+W \mu_{2}+e_{2} \\
Y=\alpha_{4}+c^{\prime} X+b M+W \mu_{3}+e_{3}
\end{gathered}
$$

where $M$ represents farmers' perceptions of technology, including economic perceptions, health perceptions, and environmental perceptions, and Equation (4) examines the link between biopesticides technical training participation behavior and biopesticide adoption behavior. Equation (5) investigates the relationship between biopesticide technical training provided by cooperatives and farmers' perceptions of technology. The mediation effect testing procedure is divided into four steps. First, suppose both $c$ and $a$ are significant. In that case, Equation (6) continues to be estimated to test whether the biopesticides technical training provided by agricultural cooperatives and farmers' perceptions of technology are related to the biopesticide adoption behavior of farmers. Second, suppose $a$ and $b$ are both significant. In this case, there is a mediating effect of farmers' perceptions of technology on the relationship between the biopesticide technical training provided by agricultural cooperatives and biopesticide adoption behavior. If at least one is not significant, go to step 4 directly. Third, test whether the coefficient $c^{\prime}$ is significant. When $c^{\prime}$ is significant and $c^{\prime}<c$, there is a partial mediating effect. When $c^{\prime}$ is not significant, there is a full mediating effect. Fourth, the Sobel test is conducted according to the results of the second step. If there is a mediating effect, the value is $a b$, and the proportion of the mediating effect of $X$ through $M$ on $Y$ to the total effect of $X$ on $Y$ is $a b / c$.

\subsection{Data}

As one of the world's four most cultivated fruits, citrus has a wide planting area. Its green production behavior has a broad impact on human health and the environment, especially in mountainous and hilly regions. According to the National Bureau of Statistics of China (NBSC), in 2018, China's citrus planting area reached 2.6 million hectares, and its output was 41,381,400 tons, ranking first in the world in both aspects [46]. At the same time, based on the statistical data from NBSC, the total area of citrus in Sichuan, the terrain of which is mainly mountainous and hilly, located in the upper reaches of the Yangtze River, was about 2041 hectares, with a production of 4.3298 million tons, ranking fourth in China. Because of the vast area of citrus cultivation in Sichuan on the upper reaches of the Yangtze River, the use of biopesticides by citrus growers affects the local environment in addition to the environment in the middle and lower reaches of the Yangtze River. Thus, this study selected Sichuan Province as the investigation area.

The data used in this study were derived from a field survey conducted between July and August 2020 in Sichuan Province, in the south-west of China. A multistage sampling procedure was employed to select household samples that supported the empirical analysis 
of this study. After the purposive selection of the three major economic zones, nine counties were deliberately chosen, using a stratified sampling approach based on the distribution of citrus yield and the total number of agricultural cooperatives specialized in citrus production and marketing. These included Pujiang, Dongpo, Renshou, Danling, Yanjiang, and Zanyue in Chengdu Plain Economic Zone, Zizhong, and Jiangan in South Sichuan Economic Zone, and Nanbu in the Northeast Sichuan Economic Zone. In the following stage, five-to-eight agricultural cooperatives were randomly selected from each of the nine counties. Finally, we randomly selected around seven members from each agricultural cooperative and around four farmers who lived near the agricultural cooperatives were not members of any agricultural cooperatives, according to the total number of members of each agricultural cooperative.

The Research Group of Agricultural Cooperatives (RGFC) members, who are experienced survey specialists, conducted the survey in the form of face-to-face interviews. A structured questionnaire was used for data collection. The questionnaire included household and farm-level characteristics (e. g., gender, age, education, village cadres, health, risk attitude, household size, planting year, household income, and agricultural income), attitudes to biopesticides, times of attending technology training, and other questions. In total, we interviewed 837 farm households.

\subsection{Variable Selection and Descriptive Statistics}

Dependent variable. Given our interest in analyzing the effect of the technical training provided by agricultural cooperatives on farmers' adoption of biopesticides, it is crucial to measure farmers' adoption of biopesticides scientifically. Following previous studies [14,22,28], our dependent variable was defined as whether or not a farmer formally adopted biopesticides in citrus planting. The dependent variable was coded as one if a farmer adopted any kind of biopesticide during the citrus planting in 2019, while zero indicated that a farmer did not adopt any biopesticides.

Independent variable. Our independent variable was the technical training participation behavior. Previous studies usually used a dummy variable for whether or not individuals participated in training to identify training participation behaviors $[9,20,22,29]$. However, attending training once and attending training more than once have noticeable differences on the effect of training [29]. For more details, our dependent variable was defined as the number of times farmers participated in technical training provided by agricultural cooperatives before they decided which kind of pesticide to use.

Mediation variables. To test the mediating effect of farmers' perceptions of technology on the relationship between the biopesticide technical training provided by cooperatives and biopesticide adoption behavior, it was necessary to measure farmers' basic perceptions of technology. Based on the previous analyses, and drawing on the approach of Constantine et al., who analyzed farmers' understanding of the impact of chemical pesticides on human health and the environment, this study measured farmers' technological perceptions by inviting farmers to fill in a five-level Richter scale questionnaire [47]. This five-level Richter scale questionnaire, shown in Table 1, included four questions used to measure farmers' perceptions of economic benefits, one question used to measure farmers' perceptions of health impacts, and one question used to measure farmers' perceptions of ecological benefits. Moreover, we also used the factor analysis method to score the farmers' perceptions of economic benefits.

Control variables. Based on previous studies $[18,21,22,35]$, we supposed variables that may have influenced the farmers' adoption of biopesticides, including the household head's gender, age, years of education, health condition, risk attitude, years of experience of citrus, and village cadre status, as well as household size, farm size, total household income, and total agricultural income. Specifically, the variables, including gender, age, education, health, household size, and so on, represented farmer households' human capital, which was expected to influence farmers' decisions regarding the adoption of biopesticides. The variables, including village cadre status, farm size, total household 
income, and total agricultural income, represented farmers' social capital, material capital, and financial capital. According to the framework of sustainable livelihoods [48], the social, material, and financial capital of farmers could also influence their adoption of biopesticides. Additionally, this study added these variables as control variables in the estimate equation.

Table 1. Definition of variables and descriptive statistics.

\begin{tabular}{|c|c|c|}
\hline Variables & Definition & Mean (S.D.) \\
\hline \multicolumn{3}{|c|}{ Dependent Variables } \\
\hline Biopesticide adoption & 1 if a farmer adopted biopesticides, 0 otherwise & $0.178(0.383)$ \\
\hline & Independent Variables & \\
\hline \multirow[t]{2}{*}{ Training } & $\begin{array}{l}\text { Number of times of participation in the biopesticide technical } \\
\text { training provided by cooperatives in } 2019\end{array}$ & $1.608(2.036)$ \\
\hline & Control Variables & \\
\hline Gender & 1 if the household head is male, 0 otherwise & $0.676(0.468)$ \\
\hline Age & Age of the household head (years) & $55.501(10.278)$ \\
\hline Education & Formal education of the household head (years) & $6.170(3.641)$ \\
\hline Village cadres & 1 if the household head is a village cadre, 0 otherwise & $0.094(0.293)$ \\
\hline Health & $\begin{array}{l}\text { Household head is very healthy }(1=\text { strongly disagree; } 2=\text { disagree; } \\
\qquad 3 \text { = general; } 4 \text { = agree; and } 5=\text { strongly agree })\end{array}$ & $3.890(0.798)$ \\
\hline Risk attitude & $\begin{array}{l}\text { Household head's risk attitude }(1=\text { risk appetite; } 2=\text { risk neutral; } \\
\text { and } 3=\text { risk averse })\end{array}$ & $2.513(0.610)$ \\
\hline Household size & Number of people residing in a household & $4.192(1.744)$ \\
\hline Farm size & Total size of citrus-planting orchards (hectares) & $1.380(4.522)$ \\
\hline Planting year & Experience in citrus planting, (years) & $13.729(10.693)$ \\
\hline \multirow{3}{*}{$\begin{array}{l}\text { Household income } \\
\text { Agricultural income }\end{array}$} & Total household income in $2019\left(\right.$ RMB $\left.1000^{a}\right)$ & $241.954(744.642)$ \\
\hline & Citrus gross revenue in 2019 (RMB 1000) & $115.012(550.683)$ \\
\hline & Mediation Variables & \\
\hline \multirow{4}{*}{ Economic perception } & $\begin{array}{l}\text { The continuous use of biopesticides can increase agricultural } \\
\text { production }(1=\text { strongly disagree; } 2=\text { disagree; } 3=\text { general; } \\
\qquad 4=\text { agree; and } 5=\text { strongly agree })\end{array}$ & $3.447(0.836)$ \\
\hline & $\begin{array}{l}\text { The continuous use of biopesticides can improve the quality of } \\
\text { agricultural products }(1=\text { strongly disagree; } 2=\text { disagree; } \\
3=\text { general; } 4=\text { agree; and } 5=\text { strongly agree })\end{array}$ & $4.059(0.68)$ \\
\hline & $\begin{array}{l}\text { The continuous use of biopesticides can increase the cost of } \\
\text { agricultural production }(1=\text { strongly disagree; } 2=\text { disagree; } \\
\qquad 3=\text { general; } 4=\text { agree; and } 5=\text { strongly agree })\end{array}$ & $3.704(0.897)$ \\
\hline & $\begin{array}{l}\text { The continuous use of biopesticides can increase the unit price } \\
(1=\text { strongly disagree; } 2=\text { disagree; } 3=\text { general; } 4=\text { agree; and } \\
\qquad 5=\text { strongly agree })\end{array}$ & $3.784(0.821)$ \\
\hline Health perception & $\begin{array}{l}\text { The continuous use of biopesticides is good for human health } \\
(1=\text { strongly disagree; } 2=\text { disagree; } 3=\text { general; } 4=\text { agree; and } \\
\qquad 5=\text { strongly agree })\end{array}$ & $3.970(0.617)$ \\
\hline $\begin{array}{l}\text { Environmental } \\
\text { perception }\end{array}$ & $\begin{array}{l}\text { The continuous use of biopesticides is good for environment } \\
\text { performance }(1=\text { strongly disagree; } 2=\text { disagree; } 3=\text { general; } \\
\qquad 4=\text { agree; and } 5=\text { strongly agree })\end{array}$ & $4.031(0.691)$ \\
\hline
\end{tabular}

Notes: ${ }^{\text {a }}$ Yuan is Chinese currency: USD 1 = RMB 6.53 in 2020.

Table 1 presents the definitions of the variables used in this study and their summary statistics. The average time spent participating in the technology training provided by agricultural cooperatives was 1.608 . Around $17.8 \%$ of the sample households used biopesticides, which indicated that biopesticides were not common in the study area and that it was necessary to popularize them. Of the respondents, $67.6 \%$ of the respondents were male; the average age of the respondents was 55.50 years, and the average length of their schooling was 6.17 years. Most farmers were healthy but risk-averse. The average household size was 4.19 members. Just $9.4 \%$ of the respondents were village cadres. Additionally, the average size of the citrus orchards was $21 \mathrm{mu}$. The average number of years of experience of growing citrus was 13.73 years. The average household and agricultural 
incomes were around RMB 241,954 and RMB 115,012, respectively, which meant that the agricultural income of the sample households accounted for $47.53 \%$ of total household income. Additionally, in our sample, $76.51 \%$ of farmers had attended technical training on the use of biopesticides. This indicates that participation in the technical training provided by agricultural cooperatives is an important factor influencing whether farmers adopt biopesticides. However, a more scientific estimation method is needed to estimate the effect of technical training.

\section{Empirical Estimation Results}

\subsection{Benchmark Model Results (Hypothesis 1 (H1).)}

Table 2 reports the base estimate for the factors affecting biopesticide adoption behavior, estimated by the Probit model using Equation (1). Because the coefficients of the explanatory variables are not straightforward to interpret, we calculate and present the results of the marginal effects estimations in the last column of Table 2. The statistical acceptance and rejection criteria for the hypotheses in statistics were as follows: a significant difference between the coefficient of the explanatory variable and 0 at the level of $10 \%$ and above indicated that the null hypothesis was rejected in a statistical sense and supported the hypothesis proposed in the paper. Accordingly, the following results were obtained. The training variable had a positive and significant impact on biopesticide adoption behavior at a $1 \%$ level, with a marginal effect of 0.026 . The marginal effect translated into an increase in the farmers' probability of adopting biopesticides of $2.6 \%$ for each time increase in farmers' participation in agricultural cooperatives' training. Our finding is consistent with the results reported by $\mathrm{Wu}$ [49], which show that the training in biopesticide technology provided by agricultural cooperatives can significantly improve the tendency of farmers to adopt biopesticides. Additionally, the more training sessions farmers attend, the more significant their effect. There are several reasons for this. First, training can increase the human capital of farmers and teach them how to use biopesticides correctly $[1,35]$. Second, agricultural cooperatives' training is not only one-time and theoretical training; it is also usually accompanied by the field management guidance services provided by agricultural cooperatives, which can reduce the production risks for farmers using biopesticides $[21,34,50]$. Third, agricultural cooperatives can improve the ability of farmers to use biopesticides and reduce the market risk of using biopesticides [18,22], which encourages farmers to adopt biopesticides. Collective actions can produce this function of agricultural cooperatives. Specifically, agricultural cooperatives can provide farmers with agricultural materials, such as biopesticides, and work as marketing channels for farmers. Thus, hypothesis 1 (H1).was confirmed.

Table 2. Estimates of the Probit model.

\begin{tabular}{ccc}
\hline Variables & Probit Model & Margins \\
\hline Training & $0.114^{* * *}(0.028)$ & $0.026^{* * *}(0.006)$ \\
Gender & $0.218^{*}(0.131)$ & $0.049^{*}(0.029)$ \\
Age & $0.001(0.007)$ & $0.000(0.001)$ \\
Education & $0.088^{* * *}(0.020)$ & $0.020^{* * *}(0.004)$ \\
Village cadres & $0.074(0.181)$ & $0.017(0.040)$ \\
Health & $0.023(0.078)$ & $0.005(0.017)$ \\
Risk attitude & $-0.097(0.091)$ & $-0.022(0.020)$ \\
Household size & $-0.026(0.033)$ & $-0.006(0.007)$ \\
Farm size & $-0.001(0.001)$ & $0.000(0.000)$ \\
Planting year & $-0.007(0.005)$ & $-0.002(0.001)$ \\
Household income & $0.001(0.001)$ & $0.000(0.000)$ \\
Agricultural income & $0.008^{* *}(0.003)$ & $0.002 * * *(0.001)$ \\
Constant & $-1.798^{* * *}(-2.99)$ & \\
Wald & $87.77^{* * *}$ & 837 \\
\hline Observations & 837 & \\
\hline
\end{tabular}

Notes: ${ }^{* * *},{ }^{* *}$, and ${ }^{*}$ represent the statistical significance at $1 \%, 5 \%$, and $10 \%$, respectively; robust standard errors are in parentheses. 


\subsection{Estimated Results Controlled the Endogeneity Issue}

To test the validity and effectiveness of the IV, we conducted two analyses. The first was the falsification test on the selected instrumental variable [50,51], and the results show that it is jointly statistically significant in the technical training participation equation $(F$-stat $=10.03 ; p$-value $=0.001)$, but not in the biopesticide adoption equation $(F$-stat $=4.24$; $p$-value $=0.235$ ). In the second analysis, we ran the OLS model for the biopesticide technical training equation and the Probit model for the biopesticide adoption equation with the inclusion of the IV. The results show that the IV had a positive and significant effect on the participation of biopesticide technical training provided by agricultural cooperatives. However, it has no significant impact on farmers' adoption of biopesticides. The findings confirm the validity and effectiveness of the IV.

In Table 3, the coefficient of the training variable in the IV-probit model is 0.137 , which is more significant than that estimated by the Probit model. This indicates that the Probit model underestimated the effects of the biopesticide technical training provided by agricultural cooperatives. The main reason for this is that the Probit model treated participation in biopesticide technical training as an exogenous variable in the regression.

Table 3. Estimates of the IV-probit model.

\begin{tabular}{cccc}
\hline \multicolumn{2}{c}{ Variables } & Training & $\begin{array}{c}\text { Biopesticide } \\
\text { Adoption }\end{array}$ \\
\hline Dependent variable & Training & & $0.137^{* * *}(0.048)$ \\
IV & Ratio of training & $3.573^{* * *}(0.171)$ & $0.219^{*}(0.127)$ \\
& Gender & $0.152(0.123)$ & $0.001(0.006)$ \\
& Age & $0.003(0.006)$ & $0.086^{* * *}(0.020)$ \\
& Education & $0.0483^{* *}(0.019)$ & $0.076(0.177)$ \\
Village cadres & $-0.334^{*}(0.202)$ & $0.019(0.073)$ \\
& Health & $0.086(0.073)$ & $-0.104(0.094)$ \\
& Risk attitude & $0.245^{* *}(0.098)$ & $-0.026(0.032)$ \\
& Household size & $0.033(0.032)$ & $-0.001(0.001)$ \\
& farm size & $0.005^{* * *}(0.001)$ & $-0.008(0.005)$ \\
& Planting year & $-0.002(0.005)$ & $0.001(0.001)$ \\
& Household income & $-0.001(0.001)$ & $0.008^{* *}(0.003)$ \\
& Agricultural income & $0.000(0.002)$ & $80.29^{* * *}$ \\
& Endogenous Wald & & $-0.461(0.844)$ \\
\hline & Constant & $0.187(0.775)$ & 837
\end{tabular}

Notes: ${ }^{* * *},{ }^{* *}$, and ${ }^{*}$ represent the statistical significance at $1 \%, 5 \%$, and $10 \%$, respectively; robust standard errors are in parentheses.

\subsection{Mediating Effect of Farmers' Perceptions of Biopesticide Technology}

Table 4 presents the results regarding the mediating effect of farmers' perceptions of technology. According to the model specification in Section 2.2, we first tested the link between the biopesticide technical training provided by agricultural cooperatives and farmers' perceptions of technology, including the perceptions of economic benefits, health benefits, and ecological benefits. Additionally, we then estimated the effects of the participation in the biopesticide technical training provided by agricultural cooperatives and farmers' perceptions of technology on farmers' adoption of biopesticides. The results are displayed in Table 4. 
Table 4. The results of the mediating effects of farmers' technology perceptions.

\begin{tabular}{|c|c|c|c|c|c|}
\hline & bles & $\begin{array}{l}\text { Economic } \\
\text { Perception } \\
\text { (Model 1) }\end{array}$ & $\begin{array}{c}\text { Health } \\
\text { Perception } \\
\text { (Model 2) }\end{array}$ & $\begin{array}{c}\text { Environmental } \\
\text { Perception } \\
\text { (Model 3) }\end{array}$ & $\begin{array}{l}\text { Biopesticide } \\
\text { Adoption } \\
\text { (Model 4) }\end{array}$ \\
\hline \multirow[t]{6}{*}{ D.V. } & Training & $0.018 *(0.010)$ & $0.022 *(0.011)$ & $-0.008(0.007)$ & $0.109^{* * *}(0.027)$ \\
\hline & Gender & $0.037(0.038)$ & $0.041(0.045)$ & $-0.003(0.035)$ & $0.215(0.132)$ \\
\hline & Age & $-0.004 *(0.002)$ & $-0.008^{* * *}(0.002)$ & $-0.004 *(0.002)$ & $0.002(0.007)$ \\
\hline & Education & $0.023^{* * *}(0.006)$ & $0.019^{* *}(0.007)$ & $-0.001(0.006)$ & $0.081^{* * *}(0.020)$ \\
\hline & Village cadres & $0.036(0.065)$ & $-0.006(0.070)$ & $-0.012(0.059)$ & $0.061(0.180)$ \\
\hline & Health & $0.056^{* *}(0.022)$ & $0.012(0.036)$ & $-0.045^{* *}(0.021)$ & $0.005(0.078)$ \\
\hline \multirow[t]{7}{*}{ C.V. } & Risk attitude & $-0.071^{* *}(0.031)$ & $-0.109^{* * *}(0.033)$ & $-0.060^{* *}(0.027)$ & $-0.079(0.093)$ \\
\hline & Household size & $0.001(0.009)$ & $0.020 *(0.012)$ & $-0.013(0.009)$ & $-0.024(0.033)$ \\
\hline & farm size & $-0.000(0.000)$ & $-0.000(0.000)$ & $0.000(0.000)$ & $-0.001(0.001)$ \\
\hline & Planting year & $0.005^{* * *}(0.002)$ & $0.008^{* * *}(0.002)$ & $0.003 *(0.002)$ & $-0.009(0.006)$ \\
\hline & Household income & $-0.000(0.000)$ & $-0.000(0.000)$ & $-0.001(0.000)$ & $0.001(0.001)$ \\
\hline & $\begin{array}{l}\text { Agricultural } \\
\text { income }\end{array}$ & $0.001(0.000)$ & $0.000(0.001)$ & $0.000(0.000)$ & $0.007^{* *}(0.003)$ \\
\hline & $\begin{array}{l}\text { Economic } \\
\text { perception }\end{array}$ & & & & $0.319^{* * *}(0.122)$ \\
\hline \multirow{3}{*}{ M.V. } & Health perception & & & & $0.326^{* * *}(0.103)$ \\
\hline & $\begin{array}{l}\text { Environmental } \\
\text { perception }\end{array}$ & & & & $-0.100(0.110)$ \\
\hline & _cons & $3.611^{* * *}(0.191)$ & $4.242^{* * *}(0.257)$ & $3.603^{* * *}(18.05)$ & $-1.453^{* *}(0.728)$ \\
\hline
\end{tabular}

The coefficients of the biopesticide technical training provided by agricultural cooperatives in model one and model two were significantly positive. The coefficients of farmers' perceptions of technology's economic and health benefits in model four were also significant. These indicate that farmers' perceptions of biopesticides' economic benefits and health benefits play partial mediating roles in the relationship between the biopesticide technical training provided by agricultural cooperatives and farmers' biopesticide adoption behavior. Further calculations demonstrated that the mediating effect of the perception of economic benefits was 0.006 , accounting for $4.19 \%$ of the total effect. That is, $4.19 \%$ of the impacts of the biopesticide technical training provided by agricultural cooperatives on farmers' biopesticide adoption behavior was via the farmers' perception of biopesticides' economic benefits. Since citrus is grown mainly for sale, citrus growers pay close attention to inputs and outputs in the production process. Agricultural cooperatives usually first explain the economic benefits of using biopesticides to farmers when implementing technical training to improve the likelihood of farmers adopting biopesticides. Specifically, after being trained, farmers understand that the long-term use of biopesticides can enhance the quality of agricultural products, which helps them obtain higher sales revenue. Therefore, agricultural cooperative technical training can guide farmers to use biopesticides by influencing their perception of the economic benefits of biopesticides. In addition, we conducted a Sobel test to further examine the significance of the mediating effect. The results showed that the mediating effect of the perceptions of biopesticides economic benefits was statistically significant at the level of $1 \%$, indicating that there was indeed a mediating effect of these perceptions about biopesticides. Thus, hypothesis $2 \mathrm{a}$ (H2a). was supported.

Following the same calculation method, the mediating effect of farmers' perception of health benefits was 0.007 , accounting for $5.24 \%$ of the total effect. That is, $5.24 \%$ of the impacts of the biopesticide technical training provided by agricultural cooperatives on farmers' adoption of biopesticides was via farmers' perceptions of biopesticides' health benefits. The reason for this may be that agricultural cooperatives have the nature of caring for the community. During training, agricultural cooperatives explain the technology itself 
and guide farmers to pay more attention to their health. This can encourage farmers to pay attention to the impact of pesticide adoption on their health and to realize that the application of biopesticides can protect their health, thus promoting the adoption of biopesticides by farmers. Furthermore, the results of the Sobel test showed that the mediating effect of the perceptions of biopesticides' health benefits was statistically significant at the level of $5 \%$, indicating that there was indeed a mediating effect of these perceptions about biopesticides. Thus, hypothesis $2 \mathrm{~b}(\mathrm{H} 2 \mathrm{~b})$. was verified.

Meanwhile, both the coefficients of biopesticide technical training and farmers' perceptions of environmental benefits were not significant in model three or model four, indicating no mediating effect of farmers' perceptions of biopesticides' environmental benefits. This finding is consistent with the results of Wang et al. [26]. A possible reason for this estimate is that, given that their income can just meet the production and living expenses of their families, farmers are more likely to spend their limited time and money to pursue their economic interests. Specifically, farmers may pay more attention to the financial income brought by production behavior and whether it threatens their health rather than considering the impact of their production behavior on sustainable agricultural development. This is true even after being trained by agricultural cooperatives. Meanwhile, the results of the Sobel test showed that the mediating effect of perceptions of biopesticides' environmental benefit was not statistically significant. This indicates that there was no mediating effect of environmental perceptions on biopesticides. Thus, hypothesis 2c (H2c). was not verified.

\section{Heterogeneous Impact}

According to previous studies [24,27,40,52], human capital, financial capital, and labor capital are essential factors affecting farmers' adoption of biopesticides. To gain further insights into the impact of the technical training provided by agricultural cooperatives on different groups of farmers, we also examined the impact of the technical training provided by agricultural cooperatives on farmers' adoption of biopesticides for different educational levels, household incomes, and household size categories, respectively. The results presented in Table 5 generally reveal that even within other groups of farmers, the technical training provided by agricultural cooperatives tends to positively and significantly affect farmers' adoption of biopesticides.

Table 5. Effects disaggregated by groups' education, household income, and household size.

\begin{tabular}{|c|c|c|c|c|c|c|}
\hline \multirow[t]{2}{*}{ Variables } & \multicolumn{2}{|c|}{ Education } & \multicolumn{2}{|c|}{ Household Income } & \multicolumn{2}{|c|}{ Household Size } \\
\hline & $\begin{array}{c}\text { Lower-educated } \\
\text { group } \\
(\leq 6 \text { years })^{a}\end{array}$ & $\begin{array}{l}\text { Higher-educated } \\
\text { group (>6 years) }\end{array}$ & $\begin{array}{l}\text { Group with lower } \\
\text { household } \\
\text { income } \\
\text { ( } \leq 242 \text { thousands }^{\text {yuan })^{b}}\end{array}$ & $\begin{array}{c}\text { Group with } \\
\text { higher household } \\
\text { income } \\
\text { (>242 thousands } \\
\text { yuan) }\end{array}$ & $\begin{array}{l}\text { Group with } \\
\text { smaller } \\
\text { household size } \\
\text { ( } \leq 4 \text { family } \\
\text { members })^{c}\end{array}$ & $\begin{array}{c}\text { Group with larger } \\
\text { household size } \\
\text { (>4 family } \\
\text { members) }\end{array}$ \\
\hline Training & $0.083(0.055)$ & $0.111^{* * *}(0.034)$ & $0.138^{* * *}(0.041)$ & $0.071 *(0.036)$ & $0.198 * * *(0.060)$ & $0.069 * *(0.031)$ \\
\hline Control variables & Controlled & Controlled & Controlled & Controlled & Controlled & Controlled \\
\hline Constant & $0.325(1.086)$ & $-0.535(0.718)$ & $-0.726(0.792)$ & $-2.401 * *(1.208)$ & $-1.140(1.022)$ & $-1.587^{* *}(0.776)$ \\
\hline Observations & 408 & 429 & 661 & 176 & 322 & 515 \\
\hline
\end{tabular}

Notes: (a) The average education of the sample household heads is six years;(b) 242,000 yuan is the average sample household total income; (c) Four is the average number of sample household family members. ${ }^{* *}$, **, and * represent the statistical significance at $1 \%, 5 \%$, and $10 \%$, respectively; robust standard errors are in parentheses.

\subsection{Disaggregated Effect by Educational Level}

The results, presented in columns two and three of Table 5 , indicate that the coefficients of the training variable in the lower- and higher-education groups were 0.111 and 0.121 , respectively. However, only the coefficient of the training variable in the higher-education group was positive and significantly different from zero. These suggest that the statistically significant and positive effects of the technology training provided by agricultural cooperatives on farmers' biopesticides adoption behavior were only felt in the highereducational-level group, without being present in the lower educational level group. A possible reason for this is that education level is an essential indicator of the human capital 
of farmers invested in production. The human capital accumulated through education can help farmers improve their ability to recognize new concepts, such as when accepting new knowledge and acquiring information related to new technologies [53]. More highly educated farmers are more open-minded and rational when analyzing the advantages of new technologies. As a result, when they attend the technical training provided by agricultural cooperatives and learn about biopesticides, they are more likely to put it into this training into practice compared to their lower-educational-level counterparts.

\subsection{Disaggregated Effect by Household Incomes}

The results, presented in columns four and five of Table 5, indicate that the coefficients of the training variable in the lower- and higher-household-total-income group were 0.138 and 0.071 , respectively. Both of the coefficients in the different education-level groups were positive and significantly different from zero. The results suggest that higher household total income attenuates the positive effect of training participation on biopesticide adoption. A possible reason for this is that, according to the survey data, the adoption of biopesticides was more common in families with higher total household income. Therefore, the degree of influence of the technical training provided by agricultural cooperatives on the adoption of biopesticides in high-income families was not as high as that in low-income families. This finding is in line with the findings by Khan et al. for Pakistan [35] and Wang et al. for China [54], which show that the higher the income of farmers, the more familiar they are with the purchasing behavior and applications of green pesticides.

\subsection{Disaggregated Effect by Household Size}

The results, presented in columns six and seven of Table 5, indicate that the coefficients of the training variable in the lower and higher household size group were 0.198 and 0.069 , respectively. Both of the coefficients in the different education-level groups were positive and significantly different from zero. The results suggest that a larger household size enhances the positive effect of training participation on biopesticide adoption. A possible reason for this is that, according to the survey data, families with more than four family members usually had more underage and elderly family members. Due to their lack of capacity for labor, the large scale of these two groups increases a family's financial burden. Compared with households with four or fewer members, farmer households with larger household sizes face more significant financial constraints on their purchasing of green means of production, such as biopesticides. This is in line with the results of Akter et al. and Hussain et al. [52,55]. As a result, farmers from larger households remain less likely to put technical training into practice, due to facing more substantial financial constraints, even after attending the technical training provided by agricultural cooperatives, compared to their smaller-household counterparts.

\section{Conclusions and Implications}

Pesticide abuse and environmental pollution are becoming more and more prominent, especially in developing countries. Biopesticides, as a green control technology with social, economic, and ecological benefits, are recommended by many sectors of society. However, they have never gained popularity. Farmers' failure to adopt new technologies is primarily due to a lack of knowledge and ability to use new technologies. This study focuses on analyzing how the training on biopesticide technology provided by cooperatives affects farmers' adoption of biopesticides and discusses the influence mechanism from the perspective of farmers' technology perceptions. The present study contributes to the body of research by providing a better understanding of the impact of technical training on farmers' adoption of biopesticides in agricultural cooperatives, using a sample of citrusproducing households in China. 


\subsection{Conclusions}

Based on a theoretical analysis and empirical estimation, some conclusions were drawn. First, attending the technical training provided by agricultural cooperatives has a positive and statistically significant effect on farmers' adoption of biopesticides, based on the descriptive statistics and empirical estimation. Second, the technical training provided by agricultural cooperatives has an impact on farmers' adoption of biopesticides by influencing their biopesticide technology perceptions. Specifically, farmers' perceptions of biopesticides' economic benefits $(4.19 \%)$ and health benefits $(5.24 \%)$ play partial mediating roles in the relationship between the biopesticide technical training provided by agricultural cooperatives and farmers' biopesticide adoption behavior. Third, the technical training provided by agricultural cooperatives has a more significant impact on biopesticide adoption behavior in households with higher-educated household heads, lower total income, and smaller size relative to their counterparts.

\subsection{Theoretical and Practical Implications}

Through the above theoretical analysis and empirical estimation, two theoretical implications and three practical implications were obtained. In terms of the theoretical implications, first, the conclusion further supports the theory of human capital by pointing out that technical training can indeed promote farmers' acceptance of new technologies by changing their understanding of these technologies. Second, the conclusion further enriches the cooperative theory by verifying the positive role of agricultural cooperatives in technology extension. In terms of the practical implications, first, the conclusion provides empirical evidence for the further popularization of biopesticides, that is, by encouraging the full adoption of agricultural cooperatives' technical training function. Second, the research conclusions point out the direction for further improving the training effect of agricultural cooperatives. That is, the training objects of agricultural cooperatives should focus on households with lower total income and of smaller size. Third, the conclusion of the study provides a new approach to the further exploration of the training effect of cooperatives, that is, by emphasizing the economic value of new technologies and their benefits to farmers' own health during their training in the use of new technology (i.e., biopesticides).

\subsection{Limitation and Future Research Direction}

A limitation of this study is that we only focused on citrus farmers in China, without considering other cropping activities. Given the increasing significance of technical training provided by agricultural cooperatives in improving the probability of farmers' adoption of biopesticides, further studies incorporating other crops and other regions are necessary to test the external validity of our findings. Additionally, this may help to improve our understanding of the effect of technical training on agricultural technology adoption in a broader context. Additional important questions for future research could include an investigation of the training effects from different training organizations by adopting the same training form, in addition to the differences among the same kinds of training organization by adopting other training forms.

Author Contributions: Conceptualization, Y.L. and X.F.; theoretical framework, R.S. and W.W.; methodology, Y.P. and Y.L.; investigation, X.F. and Y.P.; writing-original draft preparation, Y.L., Y.P. and R.S.; writing-review and editing, Y.L.; supervision, Y.L.; funding acquisition, X.F. All authors have read and agreed to the published version of the manuscript.

Funding: We gratefully acknowledge the funding support from the Science and Technology Department of Sichuan Province (grant no. 21RKX0020) and the Sichuan Center for Rural Development Research (grant no. CR2102).

Institutional Review Board Statement: Not applicable. 
Informed Consent Statement: This article does not contain any studies with human participants or animals performed by any of the authors. Informed consent was obtained from all the individual participants included in the study.

Data Availability Statement: The author may provide raw data if necessary.

Conflicts of Interest: The authors declare that they have no conflict of interest.

\section{References}

1. Zhang, L.; Li, X.; Yu, J.; Yao, X. Toward cleaner production: What drives farmers to adopt eco-friendly agricultural production? J. Clean. Prod. 2018, 184, 550-558. [CrossRef]

2. Zhang, W. Global pesticide use: Profile, trend, cost/benefit and more. Proc. Int. Acad. Ecol. Environ. Sci. 2018, 8, 1-27.

3. Ministry of Agriculture (MOA). Circular of the Ministry of Agriculture on Printing and Distributing the Action Plan for Zero Growth in the Application of Fertilizer by 2020 and the Action Plan for Zero Growth in the Application of Pesticide by 2020. Available online: http://jiuban.moa.gov.cn/zwllm/tzgg/tz/201503/t20150318_4444765.htm (accessed on 18 March 2015).

4. Nyangau, P.; Muriithi, B.; Diiro, G.; Akutse, K.S.; Subramanian, S. Farmers' knowledge and management practices of cereal, legume and vegetable insect pests, and willingness to pay for biopesticides. Int. J. Pest Manag. 2020, 1-13. [CrossRef]

5. Damalas, C.A.; Koutroubas, S.D. Current status and recent developments in biopesticide use. Agriculture 2018, 8, 13. [CrossRef]

6. Olson, S. An analysis of the biopesticide market now and where it is going. Outlooks Pest Manag. 2015, 26, 203-206. [CrossRef]

7. Schreinemachers, P.; Chen, H.P.; Nguyen, T.T.L.; Buntong, B.; Bouapao, L.; Gautam, S.; Le, N.T.; Pinn, T.; Vilaysone, P.; Srinivasan, R. Too much to handle? Pesticide dependence of smallholder vegetable farmers in Southeast Asia. Sci. Total Environ. 2017, 593-594, 470-477. [CrossRef]

8. Adami, A.C.O.; Miranda, S.H.G.; Delalibera, İ. Determinants of the adoption of biological control of the Diaphorina citri by citrus growers in São Paulo State, Brazil. Int. Food Agribus. Manag. Rev. 2019, 22, 351-364. [CrossRef]

9. Jiang, J.; Zhang, G.; Qi, D.; Zhou, M. Can on-the-job training stabilize employment among rural migrant workers? China Agric. Econ. Rev. 2016, 8, 498-515. [CrossRef]

10. Constantine, K.L.; Kansiime, M.K.; Mugambi, I.; Nunda, W.; Chacha, D.; Rware, H.; Makale, F.; Mulema, J.; Lamontagne-Godwin, J.; Williams, F.; et al. Why don't smallholder farmers in Kenya use more biopesticides? Pest Manag. Sci. 2020, 76, 3615-3625. [CrossRef]

11. Mengistie, B.T.; Mol, A.P.J.; Oosterveer, P. Pesticide use practices among smallholder vegetable farmers in Ethiopian Central Rift Valley. Environ. Dev. Sustain. 2017, 19, 301-324. [CrossRef]

12. Yu, L.; Zhao, D.; Gao, Y.; Yang, H.; Xu, W.; Zhao, K. Spatial dependence of family farms' adoption behavior of green control techniques in China. Agroecol. Sustain. Food Syst. 2021, 45, 767-789. [CrossRef]

13. Mannan, S.; Nordin, S.M.; Rafik-Galea, S.; Ahmad Rizal, A.R. The ironies of new innovation and the sunset industry: Diffusion and adoption. J. Rural Stud. 2017, 55, 316-322. [CrossRef]

14. Ma, W.; Abdulai, A. IPM adoption, cooperative membership and farm economic performance: Insight from apple farmers in China. China Agric. Econ. Rev. 2018, 11, 218-236. [CrossRef]

15. Wossen, T.; Abdoulaye, T.; Alene, A.; Haile, M.G.; Feleke, S.; Olanrewaju, A.; Manyong, V. Impacts of extension access and cooperative membership on technology adoption and household welfare. J. Rural Stud. 2017, 54, 223-233. [CrossRef] [PubMed]

16. Li, H.; Liu, Y.; Zhao, X.; Zhang, L.; Yuan, K. Estimating effects of cooperative membership on farmers' safe production behaviors: Evidence from the rice sector in China. Environ. Sci. Pollut. Res. 2021, 28, 25400-25418. [CrossRef] [PubMed]

17. Candemir, A.; Duvaleix, S.; Latruffe, L. Agricultural cooperatives and farm sustainability-A literature review. J. Econ. Surv. 2021, 35, 1118-1144. [CrossRef]

18. Ji, C.; Jin, S.; Wang, H.; Ye, C. Estimating effects of cooperative membership on farmers' safe production behaviors: Evidence from pig sector in China. Food Policy 2019, 83, 231-245. [CrossRef]

19. Liu, Y.; Ma, W.; Renwick, A.; Fu, X. The role of agricultural cooperatives in serving as a marketing channel: Evidence from low-income regions of Sichuan province in China. Int. Food Agribus. Manag. Rev. 2019, 22, 265-282. [CrossRef]

20. Zhou, L.; Zhang, F.; Zhou, S.; Turvey, C.G. The peer effect of training on farmers' pesticides application: A spatial econometric approach. China Agric. Econ. Rev. 2020, 12, 481-505. [CrossRef]

21. Pan, D.; He, M.; Kong, F. Risk attitude, risk perception, and farmers' pesticide application behavior in China: A moderation and mediation model. J. Clean. Prod. 2020, 276, 124241. [CrossRef]

22. Liu, Y.; Ruiz-Menjivar, J.; Zhang, L.; Zhang, J.; Swisher, M.E. Technical training and rice farmers' adoption of low-carbon management practices: The case of soil testing and formulated fertilization technologies in Hubei, China. J. Clean. Prod. 2019, 226, 454-462. [CrossRef]

23. Bhandari, G.; Atreya, K.; Yang, X.; Fan, L.; Geissen, V. Factors affecting pesticide safety behaviour: The perceptions of Nepalese farmers and retailers. Sci. Total Environ. 2018, 631-632, 1560-1571. [CrossRef] [PubMed]

24. Sharifzadeh, M.S.; Abdollahzadeh, G.; Damalas, C.A.; Rezaei, R.; Ahmadyousefi, M. Determinants of pesticide safety behavior among Iranian rice farmers. Sci. Total Environ. 2019, 651, 2953-2960. [CrossRef] [PubMed]

25. Schultz, T.W. Transforming Traditional Agriculture; Yale University Press: London, UK, 1964. 
26. Wang, H.; Wang, X.; Sarkar, A.; Zhang, F. How capital endowment and ecological cognition affect environment-friendly technology adoption: A case of apple farmers of Shandong province, China. Int. J. Environ. Res. Public Health 2021, 18, 7571. [CrossRef]

27. Khan, M.; Mahmood, H.Z.; Damalas, C.A. Pesticide use and risk perceptions among farmers in the cotton belt of Punjab, Pakistan. Crop Prot. 2015, 67, 184-190. [CrossRef]

28. Nakano, Y.; Tsusaka, T.W.; Aida, T.; Pede, V.O. Is farmer-to-farmer extension effective? The impact of training on technology adoption and rice farming productivity in Tanzania. World Dev. 2018, 105, 336-351. [CrossRef]

29. Pan, D.; Kong, F.; Zhang, N.; Ying, R. Knowledge training and the change of fertilizer use intensity: Evidence from wheat farmers in China. J. Environ. Manag. 2017, 197, 130-139. [CrossRef]

30. Pratiwi, A.; Suzuki, A. Does training location matter? Evidence from a randomized field experiment in Rural Indonesia. Agric. Food Econ. 2020, 8, 1-23. [CrossRef]

31. Mmbando, F.; Mbeyagala, E.; Binagwa, P.; Karimi, R.; Opie, H.; Ochieng, J.; Mutuoki, T.; Nair, R.M. Adoption of improved mungbean production technologies in selected east African countries. Agriculture 2021, 11, 528. [CrossRef]

32. Huang, Z.; Liang, Q. Agricultural organizations and the role of farmer cooperatives in China since 1978: Past and future. China Agric. Econ. Rev. 2018, 10, 48-64. [CrossRef]

33. Naziri, D.; Aubert, M.; Codron, J.M.; Loc, N.T.T.; Moustier, P. Estimating the impact of small-scale farmer collective action on food safety: The case of vegetables in Vietnam. J. Dev. Stud. 2014, 50, 715-730. [CrossRef]

34. Fischer, E.; Qaim, M. Linking smallholders to markets: Determinants and impacts of farmer collective action in Kenya. World Dev. 2012, 40, 1255-1268. [CrossRef]

35. Khan, M.; Damalas, C.A. Factors preventing the adoption of alternatives to chemical pest control among Pakistani cotton farmers. Int. J. Pest Manag. 2015, 61, 9-16. [CrossRef]

36. International Co-operative Alliance. Cooperative Principles. 1995. Available online: https://www.ica.coop/en/cooperatives/ cooperative-identity (accessed on 1 January 1996).

37. Zanardi, O.Z.; do Prado Ribeiro, L.; Ansante, T.F.; Santos, M.S.; Bordini, G.P.; Yamamoto, P.T.; Vendramim, J.D. Bioactivity of a matrine-based biopesticide against four pest species of agricultural importance. Crop Prot. 2015, 67, 160-167. [CrossRef]

38. Gava, O.; Ardakani, Z.; Delalić, A.; Azzi, N.; Bartolini, F. Agricultural cooperatives contributing to the alleviation of rural poverty. The case of Konjic (Bosnia and Herzegovina). J. Rural Stud. 2021, 82, 328-339. [CrossRef]

39. Othman, M.S.; Oughton, E.; Garrod, G. Significance of farming groups for resource access and livelihood improvement of rural smallholder women farmers. Dev. Pract. 2020, 30, 586-598. [CrossRef]

40. Ali, M.P.; Kabir, M.M.M.; Haque, S.S.; Qin, X.; Nasrin, S.; Landis, D.; Holmquist, B.; Ahmed, N. Farmer's behavior in pesticide use: Insights study from smallholder and intensive agricultural farms in Bangladesh. Sci. Total Environ. 2020, 747, 141160. [CrossRef]

41. Ankrah Twumasi, M.; Jiang, Y.; Osei Danquah, F.; Chandio, A.A.; Agbenyo, W. The role of savings mobilization on access to credit: A case study of smallholder farmers in Ghana. Agric. Finance Rev. 2020, 80, 275-290. [CrossRef]

42. Yu, X.; Yin, X.; Liu, Y.; Li, D. Do agricultural machinery services facilitate land transfer? Evidence from rice farmers in Sichuan province, China. Land 2021, 10, 466. [CrossRef]

43. Sampson, G.S.; Perry, E.D. The role of peer effects in natural resource appropriation-The case of groundwater. Am. J. Agric. Econ. 2019, 101, 154-171. [CrossRef]

44. Wolske, K.S.; Gillingham, K.T.; Schultz, P.W. Peer influence on household energy behaviours. Nat. Energy 2020, 5, 202-212. [CrossRef]

45. Baron, R.M.; David, A. Kenny Einheitliche Zeichensprache bei Untersuchung Lungenkranker. J. Pers. Soc. Psychol. 1986, 51, 1173-1182. [CrossRef] [PubMed]

46. National Bureau of Statistics of China. China Statistical Yearbook; China Statistcs Press: Beijing, China, 2018.

47. Iliopoulos, C.; Valentinov, V. Member heterogeneity in agricultural cooperatives: A systems-theoretic perspective. Sustainability 2018, 10, 1271. [CrossRef]

48. Sen, A.K. Development as Freedom; Oxford University Press: Oxford, UK, 1999.

49. Wu, J. Individual endowment, risk preference and peasants' selection of green pesticides. Chem. Eng. Trans. 2018, 65, 745-750. [CrossRef]

50. Pizer, S.D. Falsification testing of instrumental variables methods for comparative effectiveness research. Health Serv. Res. 2016, 51, 790-811. [CrossRef]

51. Ma, W.; Zhou, X.; Renwick, A. Impact of off-farm income on household energy expenditures in China: Implications for rural energy transition. Energy Policy 2019, 127, 248-258. [CrossRef]

52. Akter, M.; Fan, L.; Rahman, M.M.; Geissen, V.; Ritsema, C.J. Vegetable farmers' behaviour and knowledge related to pesticide use and related health problems: A case study from Bangladesh. J. Clean. Prod. 2018, 200, 122-133. [CrossRef]

53. Jallow, M.F.A.; Awadh, D.G.; Albaho, M.S.; Devi, V.Y.; Thomas, B.M. Pesticide knowledge and safety practices among farm workers in Kuwait: Results of a survey. Int. J. Environ. Res. Public Health 2017, 14, 340. [CrossRef]

54. Wang, W.; Jin, J.; He, R.; Gong, H.; Tian, Y. Farmers' willingness to pay for health risk reductions of pesticide use in China: A contingent valuation study. Int. J. Environ. Res. Public Health 2018, 15, 625. [CrossRef]

55. Hussain, S.; Siddique, T.; Saleem, M.; Arshad, M.; Khalid, A. Chapter 5-Impact of Pesticides on Soil Microbial Diversity, Enzymes, and Biochemical Reactions, 1st ed.; Elsevier Inc.: Amsterdam, The Netherlands, 2009; Volume 102, ISBN 9780123748188. 